\title{
COMPARISON OF REQUIREMENTS FOR VIBRATION-BASED CONDITION MONITORING OF A VERTICAL-AXIS VS. HORIZONTAL-AXIS WIND TURBINE
}

\author{
Leszek KOTULSKI, Adam JABLONSKI \\ AGH University of Science and Technology, kotulski@agh.edu.pl \\ AGH University of Science and Technology, ajab@agh.edu.pl
}

\begin{abstract}
The paper compares the requirements for vibration-based condition monitoring system for two seemingly similar rotary machines, namely horizontal and vertical-axis wind turbines. The paper shows that the differences in the design have a significant influence on both, operational parameters and wind energy conversion, and what are the consequences from condition monitoring point-of-view. In addition, the authors present a list of obstacles during worldwide development of vibration-based guidelines, which has led to major constraints within practical data acquisition and processing. Finally, the paper presents comparison of experimental data and complete schemes of mechanical components of drive trains of both types of turbines.
\end{abstract}

Keywords: wind turbine, condition monitoring, vibrations

\section{PORÓWNANIE WYMAGAŃ SYSTEMU MONITOROWANIA I DIAGNOSTYKI DLA TURBIN WIATROWYCH O POZIOMEJ I PIONOWEJ OSI}

\section{Streszczenie}

W artykule porównano wymagania dla systemu monitorowania dwóch pozornie podobnych maszyn wirnikowych, mianowicie turbin wiatrowych o poziomej i pionowej osi obrotu wału głównego. Autorzy pokazali analizę, z której wynika, że różnice w konstrukcji mają znaczący wpływ zarówno na parametry eksploatacyjne, jak i na konwersję energii wiatrowej oraz jakie są konsekwencje tych różnic $\mathrm{z}$ punktu widzenia oceny stanu technicznego. Ponadto, autorzy przedstawili listę powodów, które sprawiły, że do dnia dzisiejszego, światowym organizacjom udało się opracować się jedynie normy odnoszące się do analizy niektórych typów maszyn w wąskim przedziale warunków operacyjnych. Na koniec przedstawiono porównanie danych eksperymentalnych i schematów mechanicznych elementów układów napędowych obu typów turbin.

Słowa kluczowe: turbiny wiatrowe, ocean stanu technicznego, drgania

\section{INTRODUCTION}

As estimated recently by scientists [1], the wind energy available on Earth is roughly twenty times greater than our today's needs. This energy is nowadays being captured just in trace amounts by various wind power generators called "wind turbines" (WT). A typical WT is a modern version of ancient windmills and wind-driven Buddhist prayer wheels. Today, wind turbines are generally made of steel and composite, and are placed on concrete foundations. Furthermore, they are equipped with sophisticated electronics, control units and condition monitoring systems. Due to environment protection and global economics, in recent years, wind energy has placed a solid role in renewable power generation sector. Just in 2017 , the global newly installed wind capacity exceeded $50 \mathrm{GW}[2]$, which means that wind turbines have reached about $4 \%$ contribution to total world power generation [3]. In order to maximize the power generation efficiency followed by highest possible total revenue over entire life cycle, many research projects have been conducted $[4,5,6,7]$, and as a result, many different designs of wind turbines have been proposed over the years in different parts of the world, including mixed designs [8]. Wind turbines are often classified not with respect to their operation design, but with respect to location, like on-shore vs. off-shore wind turbines. According to the axis of rotation of the main shaft, wind turbines could be classified either as horizontal or vertical ones. Currently, the most common design worldwide is definitely a 3-blade horizontal wind turbine; however, vertical wind turbines become more popular every year [9].

The increasing popularity of vertical wind turbines comes from a few major significant advantages over popular, ubiquitous horizontal turbines. These advantages could be classified into three groups, namely environmental, business, and mechanical features. From environment point-ofview, in contrast to horizontal WTs, vertical axis WTs are free from electromagnetic interference [10]. Next, vertical axis WTs have few times smaller blade rotation space than horizontal WTs. 
As a consequence, they generate less noise (up to $50 \mathrm{~dB}$ difference between vertical and horizontal WTs). From engineering, or mechanical point-ofview, vertical WTs are simpler designs, which makes them less error-prone. Firstly, vertical axis WTs operate without steering mechanism, which means that the tower does not have to rotate to the current direction of the wind. In case of vertical WTs, this mechanism (so-called "yaw rotation") requires a set of electrical motors and distributed breaking system. Anytime, this system is engaged, it excites natural frequencies of the nacelle and the tower, which requires additional constraints on data acquisition logic within condition monitoring system. Tertiary, in contrast to horizontal WTs, vertical axis WTs operate without a gearbox, which not only reduces the condition monitoring requirements, but also frees the tower from large weight directly on its top. Finally, from business point-of-view, vertical axis WTs are characterized by $70 \%$ power generation efficiency vs. $50 \%-60 \%$ for horizontal axis WTs (i.e. conversion of wind kinetic energy into electromechanical power $[1,9])$.

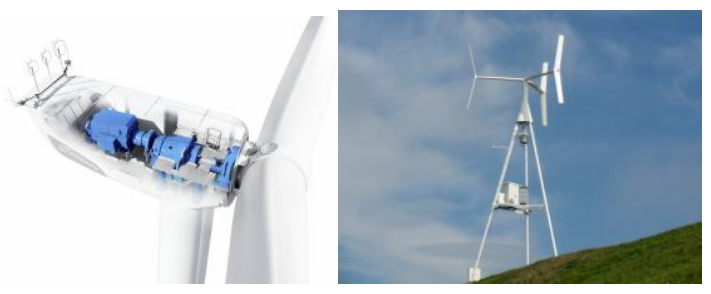

Fig. 1. Types of wind turbines. Left: horizontal [source: Nordex SE], right: vertical [http://www.anew-institute.com]

Summarizing, it could be stated that generally vertical wind turbines are more human and birds friendly, they have better unit revenue, and are much cheaper in maintenance. The current study compares the dynamics of a vertical axis wind turbine and horizontal axis wind turbine from the vibration-based assessment of the technical condition of wind turbines, which is a major task of commercially installed condition monitoring system. The paper is organized as follows. Chapter 2 explains the distribution of dynamic forces for both types of wind turbines. Chapter 3 illustrates exemplary operational WT data.

\section{DYNAMIC FORCES DISTRIBUTION}

The basic operation difference between a horizontal and a vertical wind turbine is such that the first takes advantage of rotational aerodynamic forces, whereas the latter one is driven by linear motion aerodynamic forces. As a consequence, horizontal WT generates a rotation of air in a shape of a disc, while a vertical WT generates a rotation of air in a shape of a cylinder, which is illustrated in Fig. 2.

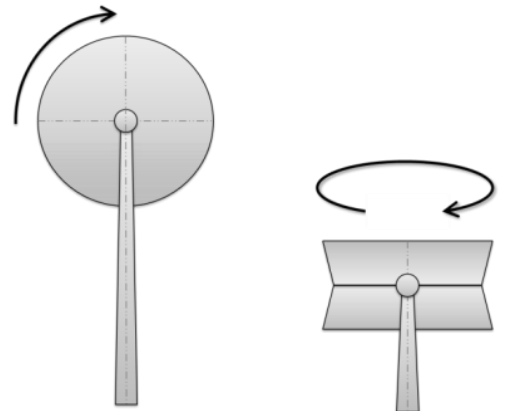

Fig. 2. Aerodynamic shape generated by a horizontal WT (left) and a vertical WT (right)

During a full rotation of blades of a horizontal WT, the blades are continuously exposed to a cyclic, variable load, which is a sum of constant gravitational force and variable inertial force. This resultant force is a source of undesired fatigue. In contrast, for vertical axis WTs, both, the gravity and the inertial force are constant, and thus the blades are subject to a constant load resulting in significantly reduced fatigue. However, for such Darrieus design, where each blade generates maximum torque at precisely two points of rotation, the power cycle generates a sinusoidal pulsing.

As claimed by manufacturers of vertical WTs, these turbines might reach higher wind power conversion than horizontal WTs [9]. This is simply explained by the fact that in case of vertical WTs, the same air flow meets blades twice. At first, the air comes in contact with a blade when it enters the turbine, and second time, when the air flow leaves the turbine. In case of a single-blade horizontal design, this scenario takes place only if the time needed for one full rotation of the tower precisely equals the time needed for the wind to travel across the formulated cone, which is challenging. In industrial designs, few blades are used, so that the same wind transfers its power even if the rotational speed of a turbine is much lower than the speed of the wind. Moreover, vertical wind turbines enable faster wind speed recovery, so they could be located denser. As claimed in [11], in general, horizontal WTs need to be separated ten times their width due to wind disturbances, as illustrated in fig. 3 .

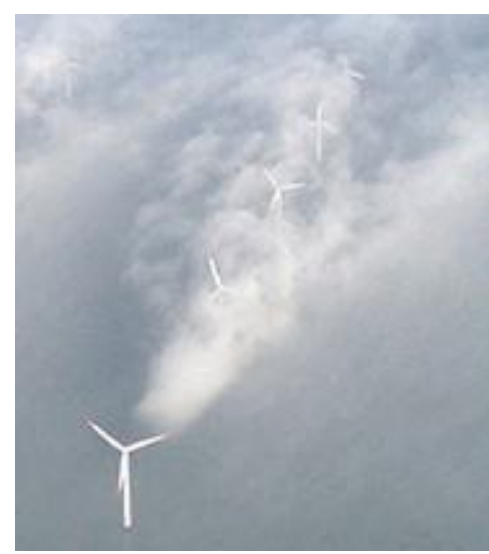

Fig. 3. [source: google "Free to use share or modify" images] 
In addition to different load distribution and inertial forces, wind turbines are also affected by additional loads from variable operating conditions. Superposition of these external conditions onto these operating conditions results in variable load on the entire WT, regardless of the design. Main operating factors include output power and speed, with different effect on individual mechanical parts, i.e. rotor, the drive train, the tower and foundation. In consequence, both, the frequency response functions as well as excitation functions are different for different designs of wind turbines, which constitutes a major detrimental factor for formulation of suitable vibration-based guidelines and proper parametrization of commercial condition monitoring systems $[1,12]$.

\section{OPERATION OF TURBINES}

\subsection{Horizontal wind turbine}

The rotor of horizontal-axis WT contains a rotor hub with blades, which are fixed (so-called stallcontrolled) or turn with respect to the longitudinal axis. The hub is connected rigidly to the main shaft, which is the first component of the drivetrain. Two types of drivetrains exist. The first design contains a gearbox, which speeds up the rotor speed approximately one hundred times. In the second, so-called "gearless" design, the hub is directly connected by a shaft with the generator's rotor. The main shaft, possible gearbox, and the generator are encapsulated in a one big housing called a "nacelle". The nacelle is connected to the tower via bearings. The tower is fixed to its foundation, which for onshore turbines is the ground, while for offshore WTs could be either the seabed or some kind of a floating buoy. As a consequence, rotor blades and the rotor hub are exposed to both, asymmetric incoming flow and random wind-speed fluctuations. These asymmetric flows are caused by gusts, wind turbulence, off-axis flow into rotor, and finally different wind-speeds distributed over the rotor surface. These vibrations are partially transferred to remaining components of the drivetrain.

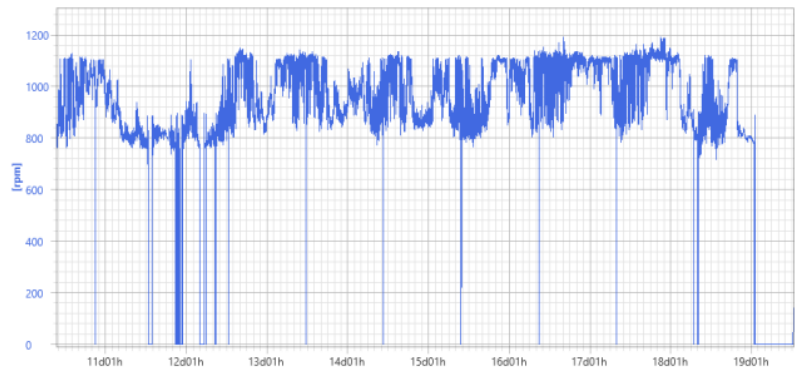

Fig. 4. Rotational speed of a horizontal wind turbine with three blades

Fig. 4. illustrates an exemplary profile from a 2.5 MW horizontal wind turbine. As illustrated, the speed of the generator's fast shaft is in the range
750 to 1200 RPM, which means that the main shaft operates roughly at 7-12 RPM. A typical horizontal WT, like N100/2500 operates at wind speed from $3 \mathrm{~m} / \mathrm{s}$ to $20 \mathrm{~m} / \mathrm{s}$ giving the rated $2.5 \mathrm{MW}$ power above $13 \mathrm{~m} / \mathrm{s}$.

\subsection{Vertical wind turbine}

Most designs of vertical WT are based on the Darrieus design and are much simpler that vertical WTs. Such turbines have a number of blades mounted on a vertical rotating shaft. While some vertical WT have curved aerofoil blades, others, like the Anew -S1 under particular investigation has straight vertical blades. This type of a vertical WT is also called "H-rotor" or "Giromill" design.

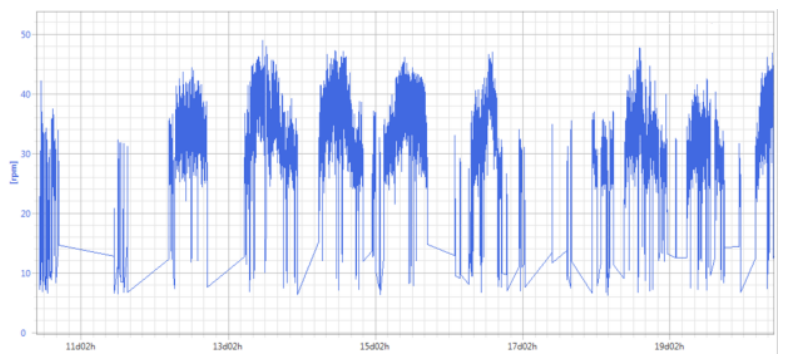

Fig. 5. Rotational speed of a vertical wind turbine with three straight blades

As illustrated in fig. 5, the rotational speed of the vertical WT under investigation is in the range from 20 to 48 RPM. In comparison with the horizontal WT, although from fig. 5. it might be concluded that the rotational speed of the main shaft of a vertical wind turbine is approx. 3-4 times bigger; the linear speed of the tips of blades is comparable, because for studied examples, the blades of a horizontal wind turbine are about three times longer than the radius of the disc generated by rotating blades of the vertical turbine. An exemplary ANew-S1 operates at much lower wind speed comparing to the horizontal one, namely form 3 to $9 \mathrm{~m} / \mathrm{s}$.

\section{LEGAL STANDARDS}

Due to large popularity of horizontal, 3-blade wind turbines, the notion of "wind turbine" condition monitoring (CM) is frequently limited particularly to these design. However, from dynamics-point-of view, vibration-based CM need to distinguish at least five major groups of WTs, significantly varying in generated vibrations, namely:

- onshore horizontal WTs with geared drivetrain,

- offshore horizontal WTs with geared drivetrain,

- onshore gearless horizontal WTs,

- offshore gearless horizontal WTs,

- vertical WTs.

Starting with normative documents, it is worth to mention that currently, only onshore horizontal WTs with geared drivetrain are covered by ISO standards. As claimed in [13], the special nature of 
wind turbines in general prohibits popular existing standards (e.g. ISO 4866, DIN 4150-3) from application towards evaluation of their vibrations level. In fact, general standards like ISO 10816-1 or ISO 7919-1 could be applied for some components of a WT (bearings, gears, shafts, and generator) only if the vibrations generated by these components are free from other excitations, which is unavoidable especially for offshore WTs, where vibrations of the tower or nacelle are excited by wind and sea swell. As claimed in [13], the subsequent part after the ISO 10816-21, i.e. ISO 10816-22 devoted to onshore installations with generators coupled to rotor without a gearbox (direct drive) is under preparation. However, at the same time ISO 10816-21 states that the normative guidelines for offshore WTs with generators with a gearbox as well as for offshore installations with generators coupled to the rotor without a gearbox (direct drive) have not yet been started, because the International Organization for Standardization has not collected sufficient amount of data. Furthermore, ISO18816-21 puts additional constraints on WTs, which could be monitored according the standard, namely between $10 \mathrm{~kW}$ and 3MW, which makes it inapplicable for modern 6 MW designs. Finally, worth mentioning, the standard is constrained to values generated by analysis of signals recorded under stable operation and are not suitable for early detection of faults, which frequently is most desirable in WTs condition monitoring. In conclusion, the latest released ISO 10816-21 standard for evaluation of acceptable vibration levels for WTs is limited in both, scope and functionality, and does not apply to horizontal designs. Actually, the conducted research has proven that international standards cover for instance manufacturing process of vertical WTs (e.g. ISO 9001), but standards referring to permissible vibration levels are not available yet.

\section{CONDITION MONITORING}

\subsection{Overview}

In general, vibration-based condition monitoring aims at detection of unacceptable vibration level of a baseband signal or its filtered and processed version, possibly followed by identification of a mechanical component responsible for generation of excessive vibrations. In more optimistic scenario, it might be further possible to assess the severity of the fault and estimate the Remaining Useful Life (RUL), i.e. time, when the wind turbine component is likely to experience a catastrophic failure. While the first two tasks have been successfully implemented over the years, severity assessment followed by RUL estimation is still in development stage, and many researches are being conducted, like described in [4]. A successful deduction resulting in fault detection requires a suitable processing of data, which contains the information about the fault. Because both, vertical and horizontal WTs operate according to different load distribution (external excitation), in different speed range (internal excitation), and significantly differ in mechanical designs (structural responses), the data acquisition system and data processing algorithms should be adjusted to both designs, separately.

\subsection{Blades}

In case of horizontal WT, the fundamental harmonic of natural frequency of a blade is typically in range from $12.7 \mathrm{~Hz}$ to $36.6 \mathrm{~Hz}$ [14], which means that this frequency might coincide with either generator excitation frequency. For instance, for a popular horizontal 2.5 MW 90/2500 $\mathrm{WT}$, the operating range is $740-1,300 \mathrm{rpm}(12,3-$ $21,7 \mathrm{~Hz}$ ). This manufacturers data is additionally endorsed by experimental measurement illustrated in fig. 4. Analogously for vertical WTs, for particular rotational speed of blades, the sinusoidal pulsing power cycle might coincide with the natural frequency of the blades, causing their damage. Therefore, for both types of WTs, it is a common practice to install additional set of brakes, which prevent from operation at natural frequencies, i.e. to avoid such situation, where the rotational speed of any of shafts coincides with the natural frequency of the blades. Because the blade pass frequency (BPF) is important to monitor, taking into account the minimum rotating speed of a vertical WT, the frequency range of an accelerometer should start at no more than: $20 \mathrm{RPM} * 3=1 \mathrm{~Hz}$, which is common. However, for horizontal WT, the BPF is about three times less, which requires accelerometers with lower starting range (typically more expensive).

\subsection{Tower and nacelle}

The total weight of Anew $-\mathrm{S} 1$ is about 18 tons, which is three times less than the tower of a popular vertical WT, about 55 tons. This means that the structural frequencies of smaller, vertical wind turbines are higher comparing to horizontal ones, which again calls for more customized sensors for the latter ones. It might be concluded that this is the reason, why ISO 10816-21 states that condition monitoring of a horizontal WT nacelle and tower requires measurement in a frequency range starting no higher than $0.1 \mathrm{~Hz}$, which for specialized, high class, relatively expensive sensors. Moreover, it is advised to measure acceleration and velocity on both sides of the mounting of the main bearing, as well as on the front and back side of the generator's mainframe. In addition, the measurements should be taken in all three directions, which calls for three-axial sensors.

\subsection{Drivetrain}

Fig. 6. illustrates a complete scheme of a typical 3-blade horizontal wind turbine with a planetary gearbox and 2-stage parallel gearbox. A typical, 


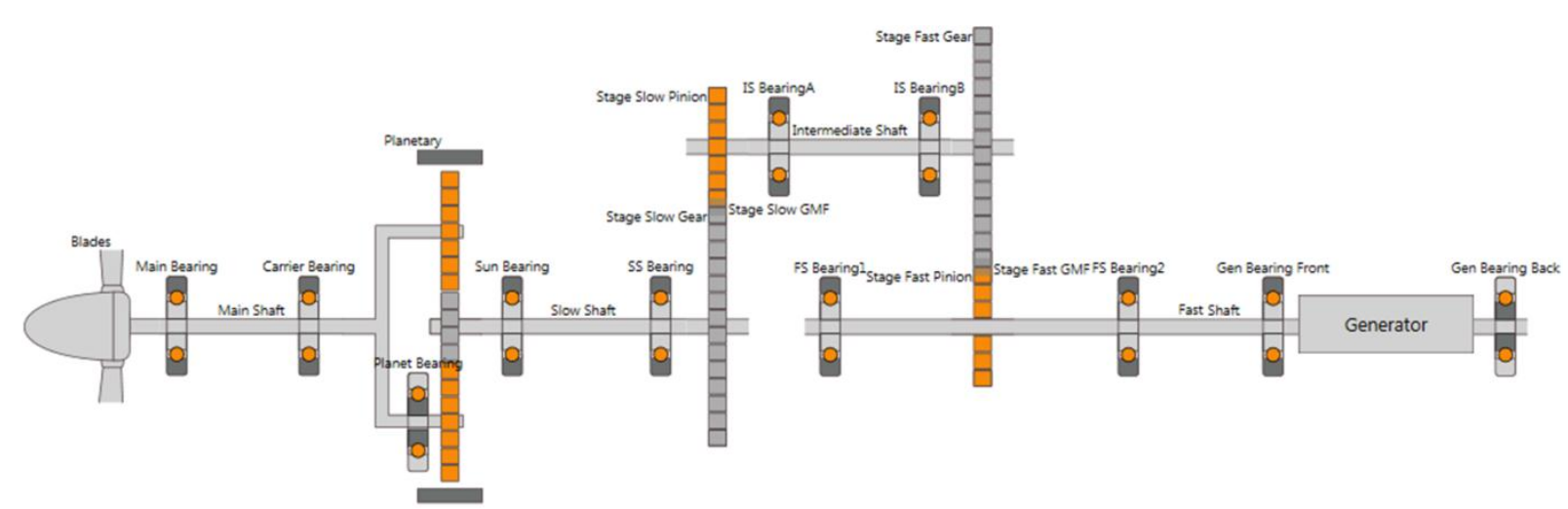

Fig. 6. Drivetrain scheme of a horizontal WT

vibration-based condition monitoring system (CMS) performs assessment of technical condition of shafts (main shaft, slow shaft, intermediate shaft, and fast shaft), bearings (main bearing, carrier bearing, planet bearings, sun gear bearing, slow shaft bearing, intermediate shaft bearings, fast shaft bearings and generator bearings), and gears (planetary ring gear, planet gears, sun gear, and two pairs of gears of a parallel gearbox).

Typically, for every shaft, a CMS tracks first three harmonics in order spectrum. For every rolling-element bearing (REB), few first harmonics of four characteristic frequencies are tracked in envelope order spectrum (BPFO - ball passing frequency of the outer race, BPFI - ball passing frequency of the inner race, FTF - fundamental train frequency, also called "cage frequency", and BSF - ball spin frequency). For a planetary gearbox, systems monitor frequencies corresponding to local damages on ring, sun, and planet gears. Because vibration signal from a planetary gearbox might experience various modulations, in practice, fault detection and identification of such gearbox typically requires advanced diagnostic spectral analysis. Because gearboxes are designed to operate under some speed and torque ranges, their response to different excitations might vary significantly [15]. In order to overcome this obstacle a result, it is a common practice to introduce operational states, which separate the data into proper classes, but on the other hand multiply the number of health indicators (features) to be tracked in time. As a result, the total number of features for a typical horizontal wind turbine easily exceeds a hundred. In case of a vertical wind turbine, a complete scheme of the drive train includes just the main (and only) shaft, two main shaft bearings (e.g. SKF61856 or SKF61856), and optionally two generator bearings, as illustrated in fig. 7. Typically, due to compact size and custom design, only two measurement points are used.

As a result, it might be deducted that the lack of gears allows to neglect definition of operational states, which typically is mandatory for horizontal WT. Moreover, a vertical WT requires just two measurement point in two directions, while a horizontal WT requires at least four 3-axial sensors for structural monitoring and at least six 3axial sensors for drive train monitoring. Lastly, due to higher natural frequencies and higher angular speed, the required minimum frequency range of accelerometers for vertical WT is above few $\mathrm{Hz}$, which means that standard industrial accelerometers are sufficient.

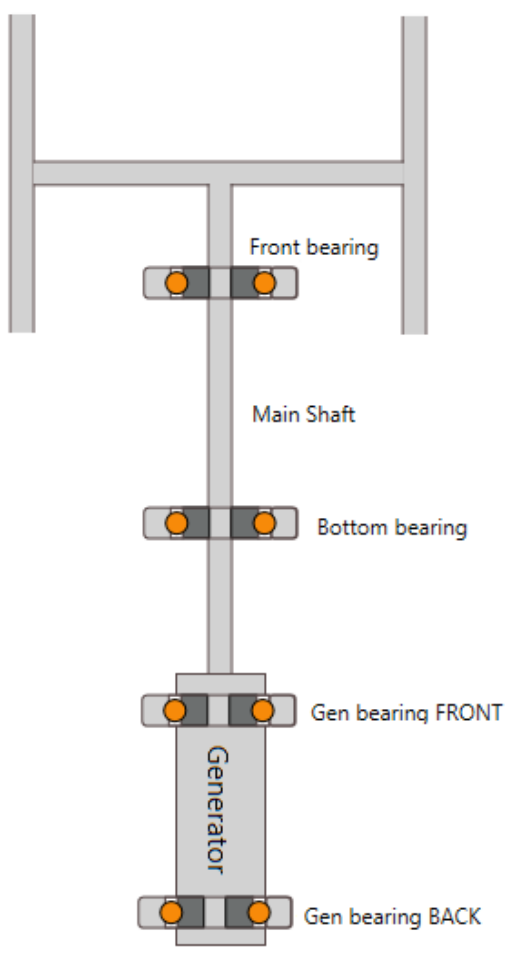

Fig. 7. Drivetrain scheme of a vertical WT

\section{CONCLUSION}

The comparison of condition monitoring of vertical and horizontal WTs shows that requirements for both of these groups vary significantly in terms of hardware, configuration, and diagnostic workload, and level of advancement of signal processing tools. As presented in the paper, the configuration of a CMS for vertical wind turbine drive train fault detection is significantly easier in comparison to horizontal WT due to simplified design and lack of gearboxes. It has been 
pointed out that the construction of the nacelle and the hub on a relatively high tower make the horizontal wind turbine an object susceptible to dangerous natural excitations, which is irrelative for vertical WTs. Finally, it has been shown that the number and the scope of documented guidelines for condition monitoring of wind turbines is scarce and limited to a single design and operation mode.

\section{SOURCE OF FUNDING}

The research has been financially supported by NCBiR, project number WND-DEM-1-153/01.

\section{REFERENCES}

1. Riley A. Fish school us on wind power. Nautilus, Issue 37, 2016.

2. Annual Global Wind Report, Global Wind Energy Council, Belgium, 2017.

3. Statistical Review of World Energy 2018, BP (British Petroleum, bp.com)

4. Sheng S, Guo Y. An integrated approach using condition monitoring and modeling to investigate wind turbine gearbox design. ASME Turbo Expo 2015;7. https://doi.org/10.1115/GT2015-43888

5. Guerrero-Villar F, Torres-Jimenez E, DoradoVicente R, Jiménez-González JI. Development of vertical wind turbines via FDM prototypes. Procedia Engineering, 2015; 132: 78-85.

https://doi.org/10.1016/i.proeng.2015.12.482

6. Bossler A, Floating Offshore Wind Foundations: Industry Consortia and Projects in the United States, Europe, and Japan, An Overview. Main(e) International Consulting, 2013.

7. Bhutta MMA, Hayat N, Farooq AU, Ali Z, Jamil SR, Hussain Z. Vertical axis wind turbine - A review of various configurations and design techniques, Renewable and Sustainable Energy Reviews. 2012 16: 1926-1939. https://doi.org/10.1016/j.rser.2011.12.004

8. Vivek CM, Gopikrishnan P, Murugesh R, Raja RM. A review on vertical and horizontal axis wind turbine. International Research Journal of Engineering and Technology (IRJET), 2017; 04.

9. http://www.anew-institute.com (2018.06.15)

10. Dvorak P. Vertical axis wind turbine technology continues to improve, Windpower Engineering \& Development, WTWH Media, LLC, 2017.

11. Li L. Vibrations Analysis of Vertical Axis Wind Turbine, PhD Thesis, Massey University. New Zealand, 2012.

12. Bartolini N, Scappaticci L, Garinei A, Becchetti M, Terzi L. Analysing wind turbine state dynamics for fault diagnosis. Diagnostyka. 2016;17(4):19-25.

13. ISO 10816-21. Mechanical vibration - Evaluation of machine vibration by measurements on nonrotating parts - Part 21: Onshore wind turbines with gearbox, International Organization for Standardization, 2015

14. Tartibu LK, Kilfoil M, Van Der Merwe AJ. Vibration analysis of a variable length blade wind turbine. International Journal of Advances in Engineering \& Technology. 2012;4(1):630 - 639

15. Noll MC, Godfrey JW, Schelenz R, Jacobs G. Analysis of time-domain signals of piezoelectric strain sensors on slow spinning planetary gearboxes.
Mechanical Systems and Signal Processing. 2016; 72: 727-744.

https://doi.org/10.1016/j.ymssp.2015.10.028

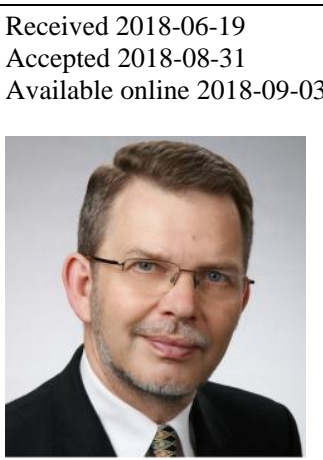

Prof. Leszek KOTULSKI, Head of the Department of Applied Computer Science, Faculty of Electrical Engineering, Automatics, Computer Science and Biomedical Engineering, AGH, Poland. Author of over 100 papers. His interests cover multi-agent systems, intelligent and smart systems, graph-based knowledge representations, and formal methods. For several years, Prof. Kotulski has been developing advanced control methods of wind turbines, especially vertical-axis WTs.

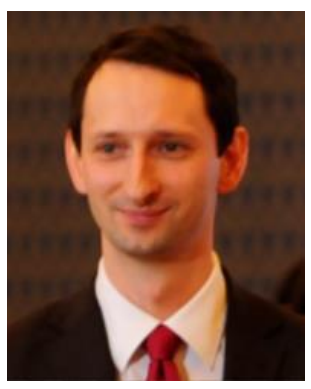

Adam JABLOŃSKI, PhD, graduated from AGH University of Science and Technology, Poland and Central Texas College, USA. Since many years, he is involved in developing customized condition monitoring systems. A fulltime Researcher at $\mathrm{AGH}$ University of Science and Technology. His main area of research interest is signal processing for diagnosis purposes. 